https://doi.org/10.17816/MAJ191S1151-152

\title{
INTEGRAL ADAPTATION RESPONSE OF THE BODY EXPOSED TO A BROADBAND STOCHASTICALLY ORGANIZED ELECTROMAGNETIC RADIATION TO A LOCALIZED PROCESS OF FORMALIN-INDUCED EDEMA CAUSING NEUROGENIC PAIN
}

\author{
A.I. Shikhlyarova, G.V. Zhukova, A.S. Goncharova, M.I. Bragina, A.A. Zhadobina,
} T.P. Protasova, E.A. Lukbanova

Rostov Research Institute of Oncology, Rostov-on-Don, Russia

\section{ИНТЕГРАЛЬНЫЙ АДАПТИВНЫЙ ОТВЕТ ОРГАНИЗМА ПРИ ВОЗДЕЙСТВИЯХ ШИРОКОДИАПАЗОННЫМ СТОХАСТИЧЕСКИ ОРГАНИЗОВАННЫМ ЭЛЕКТРОМАГНИТНЫМ ИЗЛУЧЕНИЕМ НА ЛОКАЛИЗОВАННЫЙ ПРОЦЕСС ФОРМАЛИНОВОГО ОТЕКА, ИНДУЦИРУЮЩЕГО НЕЙРОГЕННУЮ БОЛЬ}

\author{
А.И. Шихлярова, Г.В. Жукова, А.С. Гончарова, М.И. Брагина, А.А. Жадобина, \\ Т.П. Протасова, Е.А. Лукбанова
}

ФГБУ «Ростовский научно-исследовательский онкологический институт» Минздрава России, Ростов-на-Дону

The mechanism of local effects of broadband stochastically organized electromagnetic radiation (BBSO EMR) on formalin-induced edema accompanied by pain was studied at the level of integral adaptational reactions (AR). Leukogram evaluation criteria by Garkavi-Kvakina-Ukolova were used to identify types of AR and their tension (reactivity levels). Significant differences were found between the adaptation body response formed in formalin-induced edema by the type of unproductive reaction of over-activation (OA) and an integral mechanism of the bioadaptive effect of BBSO EMR - the development of stable AR of the calm (CA) and elevated activation (EA) at high reactivity levels.

Keywords: adaptational reactions; formalin-induced edema; pain; electromagnetic radiation.

На уровне интегральных адаптационных реакций (АР) исследовали механизм влияния широкодиапазонного стохастически организованного электромагнитного излучения (РШДСО ЭМИ) при локальном воздействии на процесс формалин-индуцированного отека, сопровождающегося болью. Для идентификации типа АР и их напряженности (уровней реактивности) использовали оценочные критерии лейкограммы по Гаркави - Квакиной - Уколовой. Выявлены достоверные различия между адаптивным ответом организма на введение формалина по типу непродуктивной АР переактивации, и интегральным механизмом биоадаптивного влияния РШДСО ЭМИ - развитием устойчивых АР спокойной и повышенной активации на высоких уровнях реактивности.

Ключевые слова: адаптационные реакции; формалин-индуцированное воспаление; боль; электромагнитное излучение.

Introduction. The role of neurological and immunological components as pathognomonic factors of the development of inflammatory and pain process is quite obvious. Within systemic changes at the level of the organism as a whole, the need arises to identify integral types of adaptational reactions (AR) in local pathological changes and their therapy. Fundamental scientific and applied knowledge of the patterns of the body responses depending on the intensity of an exposure factor $[1,3]$ determine the importance of defining the character of AR taking into account their periodic repetition at different reactivity levels (RL: low - LRL, moderate - MRL, high - HRL). In the management of multi-level biological systems, including the central nervous system, great opportunities are associated with wave technologies. The distant bioadaptive effect of broadband stochastically organized electromagnetic radiation (BBSO EMR) triggers a genetically determined adaptive reaction of neurons in order to regulate the excitability of cortical cells [2]. In other words, the membranotropic activity of BBSO EMR not only contributes to the local regulation of mechanisms of the neurogenic pain and inflammation, but also probably triggers the formation of AR. The purpose of the study was to reveal the dynamics of AR under the influence of local BBSO EMR on the process of formalin-induced edema.

Material and methods. The experiments included 28 white outbred male rats, 200-220 g. The inflammation and pain process was created by a $0.1 \mathrm{~mL}$ injection of $2 \%$ formalin solution $(\mathrm{F})$ to the aponeurosis of the ankle joint of the hind paw. 
The structure of integral adaptation responses during the development of local formalin-induced edema and BBSO EMR exposure

\begin{tabular}{|c|c|c|c|c|c|c|c|}
\hline Types of reactions & $\begin{array}{c}\text { Initial values } \\
n=28\end{array}$ & $\begin{array}{c}24 \mathrm{~h} \text { after } \mathrm{F} \\
n=14\end{array}$ & $\begin{array}{c}48 \mathrm{~h} \text { after } \mathrm{F} \\
n=14\end{array}$ & $\begin{array}{c}196 \mathrm{~h} \text { after } \mathrm{F} \\
n=14\end{array}$ & $\begin{array}{c}24 \mathrm{~h} \text { after F+EMR, } \\
n=14\end{array}$ & $\begin{array}{c}48 \mathrm{~h} \text { after F+EMR, } \\
n=14\end{array}$ & $\begin{array}{c}196 \mathrm{~h} \text { after F+EMR, } \\
n=14\end{array}$ \\
\hline Training, \% & 0 & 0 & 0 & 0 & 0 & $14.3^{*, * *}$ & 0 \\
\hline $\mathrm{CA}, \%$ & 21.4 & $14.3^{*}$ & $14.3^{*}$ & 0 & $14.3^{*}$ & 0 & $14.3^{*, * *}$ \\
\hline EA, $\%$ & 45.5 & $85.7^{*}$ & $71.4^{*}$ & 0 & $85.7^{*}$ & $100 *, * *$ & $85.7^{*, * *}$ \\
\hline $\mathrm{OA}, \%$ & 0 & 0 & $14.3^{*}$ & $100 *, * *$ & 0 & 0 & 0 \\
\hline
\end{tabular}

N o t e. * differs from initial values, $p<0.01$; * differs from the control group, $p<0.01$.

Parameters of the BBSO EMR generator were: frequencies from $10^{n} \mathrm{~Hz}$ to $10^{m} \mathrm{~Hz}$; integral radiated power $0.1 \mu \mathrm{W}$; frequency modulation modes were ased. Identification of AR type and RL (by signs of the reaction tension) was performed by Schilling's leukogram according to recommendations given by L.Kh. Garkavi et al. (2002).

Results and discussion. Prior to the $\mathrm{F}$ injection, all animals showed the prevalence of AR of physiological anti-stressor types - calm and elevated activation (CA, EA), predominantly of MRL, with minor tension signs in the eosinophilic and monocytic leukogram composition. 24 hours after the $F$ injection, the incidence of EA significantly increased, exceeding the initial values by 1.8 times (Table). This increase in the EA percentage in the overall structure of AR with high energy expenditure and functional activity of neuroendocrine and immune systems was accompanied by marked signs of AR tension.

In general, tensioned ARs were observed in $71.4 \%$ (28.6\% more frequent than initially). Increased tension of AR was accompanied by a discrete transition to lower RL, and this effect increased almost twice.

48 hours after $\mathrm{F}$ injections, the picture changed towards the formation of AR of the over-activation (OA) borderline with stress. OA is dangerous because a slight increase in the functional load may cause the failure of systems, first of all neuroendocrine and immune ones. This type of AR was identified in all animals with F injections after 196 hours.

The BBSO EMR exposure on day 1 after $F$ injections did not change the AR structure, compared to the control group (without BBSO EMR); in 24 hours, it was still similar: in $85.7 \%$ of cases, EA reaction, mainly LRL with tension signs, was prevalent. In 48 hours, the EA formation in animals with the BBSO EMR exposure to the area with an edema and pain increased to $100 \%$ and persisted with the transition to MRL and even HRL which accounted for $72.4 \%$ of the total sample of the main group. On day 4 (after 196 hours), the adaptation response became clearly optimized, since EA was accompanied by CA. Both physiological antistressor ARs were formed only on HRL without tension signs.

Conclusions. The adaptation response of the body in the development of formalin-induced edema which entails the development of inflammatory and pain syndromes is formed by an unproductive type of tensioned OA AR of LRL. The study allowed revealing an integral mechanism of the BBSO EMR influence which determines the transition of balanced and stable EA and CA to energetically and metabolically beneficial HRL.

\section{References}

1. Garkavi LKh, Kvakina EB, Kuzmenko TS, Shikhlyarova AI. Anti-stress reactions and activation therapy. Ekaterinburg; 2002. Part I 196 p., Part II 238 p. (In Russ.)

2. Orlov VI, Rudenko MY, Shikhlyarova AI, et al. Mechanisms of electromagnetic influences and effects on membrane systems in neurons and cardiomyocytes. Cardiometry. 2017;11:17-27.

3. Selye H. The evolution of the stress concept. Am. Scientist. 1973;62(6):642-649. 